\title{
The Hydrogen Ion Concentration of the Muscles of Marine Animals.
}

\author{
$\mathrm{By}$ \\ K. Furusawa \\ AND \\ Phyllis M. Tookey Kerridge \\ (Department of Physiology and Biochemistry, University College, London.)
}

In view of work which was in progress on the hydrogen ion concentration of mammalian muscles ( 1 and 2 ), it was thought interesting to test i he $\mathrm{pH}$ of the muscles of some marine animals. It was desired to find the $\mathrm{pH}$ of muscles immediately after, and 20-24 hours after, excision, and to make buffer curves of the change of hydrogen ion concentration with added acid and alkali. This paper is only a preliminary communication, as the buffer curves have not yet been completed. It was thought that the $\mathrm{pH}$ determinations in themselves might be of interest.

\section{Method.}

Samples of muscles (about 1 gram) were cut out of the animal with sharp scissors. The hydrogen ion concentration of the minced muscle was measured by the glass electrode method, using a portable set with a Lindemann electrometer (3). The minced tissue without dilution was placed in the electrode. All determinations were made at room temperature $\left(12-14^{\circ} \mathrm{C}\right.$.). The results are tabulated below :-

\begin{tabular}{|c|c|c|c|c|c|}
\hline \multirow{5}{*}{$\begin{array}{l}\text { Scyllium canicula } \\
\text { Homarus vulgaris }\end{array}$} & \multirow[b]{3}{*}{. } & & \multicolumn{2}{|c|}{$\mathrm{pH}$} & \multirow{3}{*}{ tail. } \\
\hline & & & \multicolumn{2}{|c|}{$\overbrace{\text { immed. after } 20-24 \mathrm{hrs} \text {. }}$} & \\
\hline & & . & $6.98(3)^{*}$ & $6 \cdot 10(5)$ & \\
\hline & . & . & $7 \cdot 03(2)$ & $6 \cdot 49(2)$ & abdomen. \\
\hline & & & & $6 \cdot 42(1)$ & claw. \\
\hline Eupagurus bernhar & rdus & . & $7 \cdot 11(2)$ & $6 \cdot 22(1)$ & abdomen. \\
\hline Maia squinado & . & . & $7 \cdot 08(1)$ & $6 \cdot 19(4)$ & abdomen. \\
\hline & & & & $6 \cdot 84(1)$ & heart. \\
\hline Pecten opercularis & . & . & $7 \cdot 13(1)$ & $6 \cdot 44(1)$ & adductor muscle. \\
\hline Conger vulgaris & . & . & & $6 \cdot 19(1)$ & tail. \\
\hline Lophius piscatorius & & . & & $6 \cdot 31(1)$ & abdomen. \\
\hline Carcinus mænas & . & . & & $6 \cdot 52(1)$ & abdomen. \\
\hline Cancer pagurus & . & . & & $6 \cdot 33(2)$ & claw. \\
\hline Holothuria nigra & . & $\cdot$ & & $6 \cdot 38(2)$ & $\begin{array}{c}\text { longit. muscle } \\
\text { body wall. }\end{array}$ \\
\hline
\end{tabular}

* The number in brackets denotes the number of experiments made in each case. 
All the specimens of crustacea used for the above experiments were hard-shelled. Experiments on soft-shelled specimens are recorded elsewhere (4).

The mean value for the normal $\mathrm{pH}$ is $7 \cdot 06$, and for the $\mathrm{pH} 20-24$ hours later 6.33. The average deviation from the latter mean value is $\pm \cdot 11$, and the probable error of the mean $\pm \cdot 10$. The one experiment on the heart of Maia has not been included in the calculation of the mean, as it is much more alkaline than the determinations on other muscles. Similar differences between cardiac and skeletal muscles have been observed in mammalia.

The chief interest in this work lies in the close agreement between the above results and those obtained by us on mammalian muscle, and by Meyerhof and Lohmann (5) on frog's muscle. A comparison is made in the following table :-

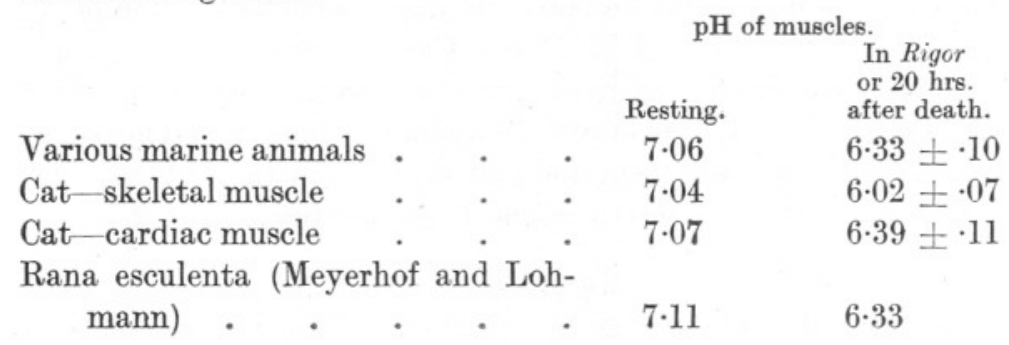

The resting values are the same in all the above cases within the limits of individual variation. In each case these values are probably more acid than pertains in the body, as acid is unavoidably produced during the excision process. It is to be inferred that approximately the same amounts of acid were formed in each technique (which was slightly different in each case). In the case of the experiments of Meyerhof and Lohmann on the frog, the muscles were put into chloroform rigor before the measurement of the figures recorded in the second column. In the experiments on cats and the marine animals, the muscles were kept 20-24 hours at room temperature, so that the post-mortem formation of lactic acid might be complete.

The $\mathrm{pH}$ of the marine animal muscles under these conditions is approximately the same as that of frogs, and of the cardiac muscle of cats. It is interesting to note that the average deviation from the mean of the $\mathrm{pH}$ measurement of the various marine specimens is not greater than that found between different individual cats. It has been shown elsewhere (4) that the amounts of glycogen present in marine muscle are comparable with that found in mammalian. It therefore appears probable that the buffering powers of the muscles are also approximately the same. 
In conclusion, we beg to offer our sincere thanks to Dr. E. J. Allen and the staff of the Marine Biological Laboratory for valuable help and hospitality.

\section{SUMMARY.}

Measurements have been made of the hydrogen ion concentration of the muscles of various marine animals immediately after death and 20-24 hours after. The results obtained are of the same order as those previously found for the muscles of the frog and the cat.

\section{REFERENCES.}

1. Katz, L. N., Kerridge, P. M. T., and Long, C. N. H. Lactic Acid in Mammalian Cardiac Muscle, Part III. Changes in Hydrogen ion Concentration (Preliminary Note). Proc. Roy. Soc., B. 99, p. 26 (1925).

2. Furusawa, K., and Kerridge, P. M. T. The Hydrogen ion Concentration of the Muscles of the Cat. Journ. Phys. (in press).

3. Kerridge, P. M. T. The Use of Glass Electrodes. Journ. Sci. Inst., 3, p. 404 (1926).

4. Hoet, J. P., And KerRidge, P. M. T. Observations on the Muscles of Normal and Moulting Crustacea. Proc. Roy. Soc. B., 100, p. 116 (1926).

5. Meyerhof, O., and Lohmann, K. Über die Vorgänge bei der Muskelermüdung. Biochem. Zeit., 168, p. 128 (1926). 
